\title{
Not a Not-Animal: The Vocation to Be a Human Animal Creature
}

\section{David Clough}

Author's pre-print version of:

Clough, David, 'Not a Not-Animal: The Vocation to be a Human Animal Creature', Studies in Christian Ethics 26:1 (2013), 4-17.

\begin{abstract}
This article diagnoses and critique two 'not-animal' modes of theological anthropology: first, the construction of human identity on the basis of supposed evidence of human/non-human difference; second, accounts of the human that take no account of God's other creatures. It suggests that not-animal anthropologies exhibit poor theological methodology, are based on inaccurate depictions of both humans and other animals, and result in problematic construals of what it means to be human. Instead, the article concludes, we require theological anthropologies that take as a starting point the relationship between humanity and God and recognise the animal and creaturely context of human existence.
\end{abstract}

\section{Keywords}

theology

anthropology

animals

difference

not-animal

ethics

\section{Article}

As my title suggests, my aim in this article is primarily negative: to diagnose and critique a problematic 'not-animal' mode of theological anthropology. In pursuing theological anthropology in this 'not-animal' mode, major Christian traditions of theological 
anthropology have been guilty of theological and factual mistakes in their rendering of the relationship between humans and other animal creatures and, as a result, theological anthropology stands in need of repair. In this 'not-animal' mode, theologians have gone about theological anthropology by looking around the world - or more commonly, drawing on accounts of philosophers who claim to have done so - listing supposed differences between humans and other animals, and building from these differences an account of the human. The resulting list of ways in which humans are not like other animals has been given a vague theological warrant through loose reference to biblical texts, with the Genesis 1.26-27 references to humans being made in the image of God a particular favourite. This 'notanimal' exercise is flawed in two key ways: first, it is an inadequate theological methodology; second, the data it has drawn upon comparing humans and other animals is inaccurate. Unsurprisingly, the theological anthropology generated in this mode is unhelpful: it fails to name adequately the particular nature and role of human beings before God; it posits a misleading and hubristic gulf between human beings and other creatures; and it founds its account of human identity on the unjustifiable denial of key characteristics to other-thanhuman animals. The consequences of these mistakes have been severe: on the one hand, humanity has been identified with particular attributes such as rationality that have marginalised those humans considered to be lacking in them; on the other hand, human exploitation of other animals has been justified on the problematic basis of the separation established by this anthropological methodology. A second kind of not-animal methodology ignores the human context among other creatures entirely: picturing human beings alone, suspended in a vacuum and considered meaningful in such isolation. In addition to their other problems, these not-animal anthropologies have been problematic for theology itself: through them the coherence of Christian theology has seemed to be at stake in the maintenance of a human/non-human divide, so that, long before debates about Darwinian evolution, but continuing through them and into the present, theologians have been forced to defend claims about differences between humans and other creatures entirely irrelevant to Christian theology properly understood.

The negative aim of demonstrating the inadequacy of not-animal theological anthropologies is intended to serve a positive one: encouraging theologians to pursue 
anthropology in a properly theological mode, alert to the status of human beings as one of God's animal creatures. To succeed in both aims, it seems to me that I need to make the case that, (1) these not-animal modes of theological anthropology exist and have been influential, (2) that they are problematic and we have reason to find them uncomfortable, and (3) that there is a mode of proceeding with the task of theological anthropology that is preferable. These three tasks of depicting, evaluating, and briefly proposing an alternative to not-animal modes of theological anthropology will structure the remainder of this article.

\section{Depicting not-animal theological anthropologies}

The most famous example of a supposed human/non-human difference being used to identify a key characteristic of humanity is that of Descartes. In his Discourse on Method, Descartes is fascinated by contemporary automata. He suggests that if there was a machine which 'had the organs and appearance of a monkey or some other irrational animal, we would have no means of recognizing that they were not of exactly the same nature as these animals'. ${ }^{1}$ In contrast, if there were a machine that was like a human body and imitated human actions, Descartes argues that we could recognise that it was a machine in two ways. First, such an automaton could not use words or signs to declare their thoughts to others; second, one would discover that it did not act through knowledge but through the disposition of its organs so that it could not respond to the full range of events in life in the way that reason allows humans to do. ${ }^{2}$ Descartes continues by observing that one can use this logic to tell the difference between 'men and beasts', since while even the most stupid person can use words to communicate, no other animal can do so. This shows not that other animals have less reason, but that they have none at all, Descartes reasons, since so little reason is necessary to speak. Animals, therefore, Descartes concludes here, do not have a mind, but nature acts in them, just like a clock. ${ }^{3}$

\footnotetext{
${ }^{1}$ René Descartes, Discourse on Method and Other Writings , trans. Frank Edmund Sutcliffe (Harmondsworth: Penguin, 1968), p. 73.

2 Descartes, Discourse on Method, p. 73.

${ }^{3}$ Descartes, Discourse on Method, pp. 74-76.
} 
While many have noted Descartes' views of other animals here, mostly with censure, few have recognised the theological context of his argument. Immediately following these comments about the difference between humans and other animals, Descartes goes on to discuss the origin of this reasonable soul, the unique possession of human beings, arguing that it could not be derived from matter, but must have been expressly created. One crucial aspect of this doctrine of the human soul, he argues, is that feeble minds are apt to be led astray if they think that he souls of animals are the same as our own, since they will then believe that we have nothing more to fear or hope for after this life than do flies or ants. If one can understand the uniqueness of the human soul, however, he suggests that one can appreciate the reasons that show that the soul is independent of the body and from this recognise that the soul is immortal in accordance with Christian doctrine. ${ }^{4}$

The structure of Descartes' account here is to use a comparison with other animals to establish that the crucial element of humanity, unique among earthly creatures, is a rational soul, and then to present this unique human possession of a rational soul as supporting evidence for the plausibility of the doctrine of the immortality of the soul. It is immediately clear that there is no opportunity within his argument for attending carefully to the actual detail of whether Descartes' observations about human/non-human difference are wellfounded. The role of other animals in Descartes' scheme is to indicate by contrast the central component of a theological anthropology; to argue that other animals might participate in rational thought would undermine not only Descartes' definition of human uniqueness but also his case for the coherence of Christian theology as such. Theological anthropology is here based, then, on a binary human/non-human categorization that simultaneously defines humanity on the basis of rationality and denies minds to all other animals, claiming that the plausibility of Christian doctrine on the maintenance of this distinction.

In fact, Descartes was not a significant innovator in relation to doing anthropology in this mode: his argument is very similar to Aristotle's method for determining the function of humanity at the beginning of the Nicomachean Ethics. Aristotle argues that the function of human beings cannot be life, because this 'seems to belong even to plants', but 'we are

\footnotetext{
${ }^{4}$ Descartes, Discourse on Method, p. 76.
} 
seeking what is peculiar to man'. ${ }^{5}$ Similarly, the life of perception seems to be shared 'even by the horse, the ox, and every animal' ${ }^{6}$ Aristotle concludes that there remains only reason that is unique to human beings and therefore constitutes their purpose. ${ }^{7}$ It is not hard to see the difficulty with this argument: following Aristotle's reasoning here, if we compared a red hammer to a blue hammer, we would be likely to deduce that its function should be found in its redness, rather than appreciating that the common function of both hammers was to strike objects. In a similar way, it might be that the most important function of human beings was something they shared with other animals and plants, such as to glorify their creator, for example. Differentiation is therefore a poor basis for deducing function.

The problem with arguments based on differentiation did not prevent them from being influential well beyond Descartes. We find very similar thoughts to Descartes' in Aquinas, who comments in the Summa contra Gentiles that the souls of dumb animals neither understand nor reason, being moved by nature, not art, citing Aristotle's $\underline{\text { Physics }}$ as an authority. Aquinas concludes, like Descartes, that this shows that only humans have a subsistent soul and the souls of other animals dies with the body. ${ }^{8}$ Later in the treatise, it is clear that the stakes are high in the denial of reason to other animals: God exercises providential care over rational creatures for their own sake, and other things only as they are directed to other goods, Aquinas argues, which means non-rational creatures are 'naturally under slavery' and can be used 'in any way whatever' by human beings. ${ }^{9}$ In the Summa $\underline{\text { theologia }}$, Aquinas even anticipates Descartes' comparison with machines. In treating the question of whether choice is found in irrational animals, he cites the objection that bees, spiders and dogs show signs of wisdom. For example, the objection goes, a hound following a stag to a crossroads eliminates two paths a stag could have taken by scent, but then takes

\footnotetext{
${ }^{5}$ Aristotle, The Nichomachean Ethics, Oxford World's Classics, ed. Lesley Brown, trans.
} David Ross (Oxford: Oxford University Press, 2009), I.7, 1097b33-34.

${ }^{6}$ Aristotle, Nichomachean Ethics, I.7, 1098a1.

${ }^{7}$ Aristotle, Nichomachean Ethics, I.7, 1098a4.

${ }^{8}$ Saint Thomas Aquinas, Summa Contra Gentiles, trans. English Dominican Fathers (London: Burns Oates \& Washbourne Ltd., 1923), vol. II, ch. 82.

${ }^{9}$ Aquinas, Summa Contra Gentiles, vol. III, pt 2, ch. 112. 
the third without trying the scent, thus showing itself capable of prudence. Aquinas responds that this appearance of reason arises from the fact that irrational animals are set in movement by divine reason, in the same way that an arrow shot by an archer, or the movements of clocks and engines are set in motion by human beings. ${ }^{10}$

This separation between human and non-human animals on the basis of reason is a commonplace in the theological tradition preceding Aquinas. Augustine, for example, bases his judgement that the commandment 'Thou shalt not kill' applies only to human beings on the basis that other animals 'have no society with us in reason, which God the Creator hath not made common both to them and us'. ${ }^{11}$ Stephen Clark argues that Augustine's view derives from the Stoic tradition that other animals do not share in reason, are not persons and cannot be members of a community. ${ }^{12}$ Stoicism does indeed seem to have been very influential in the development of Christian thinking concerning the significance of rationality. While the standard Greek definition of humanity was 'the rational animal', Stoicism placed a very particular emphasis on the significance of rationality. For the Stoics, not only is rationality an attribute which humanity shares with God, uniquely among earthly creatures, but all irrational nature exists only for the use of rational beings: in Cicero's words 'the world is as it were the common dwelling-place of gods and men, or the city that belongs to both; for they alone have the use of reason and live by justice and law..${ }^{13}$ Christians saw in Stoicism an ally

\footnotetext{
${ }^{10}$ Thomas Aquinas, Summa Theologica, trans. Fathers of the English Dominican Province, (London: Blackfriars, 1963), I-II, 13, 2. We should note that there is much more to Aquinas's thought on animals than this rote dismissal of their ability to reason. For discussions that show more positive implications of his work for animals, see Judith A Barad, Aquinas on the Nature and Treatment of Animals (San Francisco; London: International Scholars, 1995) and John Berkman, 'Towards a Thomistic Theology of Animality', in Creaturely Theology: On God, Humans and Other Animals, eds. Celia Deane-Drummond and David Clough (London: SCM, 2009).

${ }^{11}$ Saint Augustine, The City of God, ed. R. V. G. Taster, trans. John Healey (London: Dent \& Sons, 1945), bk I, ch. 19.

${ }^{12}$ Stephen R. L. Clark, The Moral Status of Animals (Oxford: Clarendon Press, 1977), 15.

${ }^{13}$ Marcus Tullius Cicero, De Natura Deorum; Academica, Loeb Classical Library, trans.
} 
in defence of key doctrines, such as God's care for human beings. One clear example of this is Origen's treatise Contra Celsum: against Celsus's view that everything was made just as much for the irrational creatures as for human beings, Origen counters that Celsus does not realise he is criticizing the Stoics, who were right to 'put man and the rational nature in general above all irrational beings, and say that providence has made everything primarily for the sake of the rational nature'.$^{14}$ Origen then engages in a length rebuttal of Celsus's supposed examples of the superiority of other animals to human beings, such as the way ants help each other with burdens, or bees live in subjection to their sovereign, judging in each case that their behaviour is merely instinct, whereas what is truly valuable is the reason that is common to human beings, heavenly beings, and God. ${ }^{15}$ As Henry Chadwick notes, this is a rehearsal of a well-established argument between Stoic and Academic philosophers, in which the Academics regularly attacked Stoic anthropocentrism in a similar way to Celsus, and Origen is mostly using stock Stoic positions. ${ }^{16}$ It seems, therefore, that theologians such as Origen saw advantage in an alliance with Stoicism in order to defend Christian claims of God's providential care of human beings, but imported with it significant chunks of Stoic thought on the connection between rationality and the divine in a way that was hugely influential on later theological accounts. ${ }^{17}$

H. Rackham (London: William Heinemann Ltd., 1933), bk 2, ch. 62 (see also ch. 14). For discussion of this aspect of Stoic thought, see Henry Chadwick, 'Origen, Celsus and the Stoa', Journal of Theological Studies 48 (1947), p. 38.

${ }^{14}$ Origen, Origen: Contra Celsum, trans. Henry Chadwick (Cambridge: Cambridge University Press, 1965), bk 4, §74.

${ }^{15}$ Origen, Contra Celsum, bk 4, $\S \S 73-99$. The similarity of this section of Origen's work with Philo of Alexandria, Philonis Alexandrini de Animalibus, Studies in Hellenistic Judaism, ed. Abraham Terian, trans. Abraham Terian (Chico, CA: Scholars Press, 1981) is also striking.

${ }^{16}$ See Chadwick's Introduction to Origen, Contra Celsum, $\mathrm{x}-\mathrm{xi}$, and also Chadwick, 'Origen, Celsus and the Stoa'.

${ }^{17}$ For a survey of the influence of Stoicism in the thought of Origen and other Christian theologians, see Marcia L. Colish, Stoicism in Christian Latin Thought Through the Sixth 
Lest it be thought that theology has long ago put this mode of thought behind it, it is worth considering a modern example of reflection on human/non-human difference. One would have thought that Karl Barth would be especially methodologically averse to the use of observations of human/non-human differences as the basis for making theological judgements, on the basis of his view that the theology should take its bearings from God's self-revelation in Christ. To his credit, in his discussions of anthropology, it is notable that Barth avoids explicitly denying particular attributes to other animals: we do not know, he observes, what Jesus Christ means for other creatures, what it means to say they are with God, what constitutes their glory, how they are the souls of their bodies, whether their lives are those of specific subjects, what kind of particularity their lives have, whether they think, whether they are rational beings, and whether the being of the world is known to them. ${ }^{18}$ Despite such confessions of ignorance, however, Barth claims to know that other creatures are not with God in the way that humans are, that humans are distinguished from other creatures in that Jesus Christ is interested exclusively in human beings, that the constitution humans have from God distinguishes them from other creatures and makes them fit to be covenant partners, that humans are distinguished from other animals in the special movement through which the Spirit gives life, and that humans are unique in their ability to desire and will in relation to God. ${ }^{19}$ If Barth had been consistent in his agnosticism about the being of other animals, clearly he could not have made claims about human uniqueness and would restricted himself to a description of the human situation without any comparative claims. Instead, he is unable to avoid the temptation to fall in with the method dominant in the

Century, The Stoic Tradition From Antiquity to the Early Middle Ages (Leiden: E. J. Brill, 1985).

${ }^{18}$ Karl Barth, Church Dogmatics, vol. III/2, ed. G. W. Bromiley and T. F. Torrance, trans. al., Harold Knight et (Edinburgh: T. \& T. Clark, 1960), pp. 137-8, 359, 374, 394-5, 399, 419-20; Karl Barth, Church Dogmatics, vol. III/1, eds. T. F. Torrance and G. W. Bromiley, trans. J. W. Edwards, O. Bussey, and Harold Knight (Edinburgh: T. \& T. Clark, 1958), pp. $140-141$.

${ }^{19}$ Barth, CD III/2, pp. 137-8, 209, 347, 359, 409. 
philosophical and theological traditions of anthropology and rely on supposed claims of human differentiation from all other creatures at key points in his theological anthropology.

David Kelsey's recent account of theological anthropology in Eccentric Existence demonstrates the possibility of doing theological anthropology without taking bearings from human/non-human difference. Kelsey bases his account of theological anthropology on humanity in relationship to God and structures his reflections about the three headings of human beings as created by God, consummated by God and reconciled to God. ${ }^{20}$ While impressive in this and many other respects, Kelsey's account exemplifies the second mode of not-animal theological anthropology referred to above: it is in danger of viewing human beings as if they were God's only creature. Given Kelsey's emphasis on Wisdom literature rather than the first chapters of Genesis as the root of theological anthropology, his omission is striking: the Psalms are full of visions of the whole of creation joining in God's praises (Pss $66.1-4 ; 98.7-8 ; 145.9-16 ; 148.7,10)$, Ecclesiastes sees the denial of the common nature and fate of humans and other animals as an aspect of vanity (3.18-19), and Job, who is particularly prominent in Kelsey's account, is told by God in no uncertain terms that he is but one small part of God's majestic creative and providential activity (Job 38-41). Yet an alien unfamiliar with life on earth would gain the impression from most of the thousand-plus pages of Eccentric Existence that human beings were the only species on earth. God's other animal creatures are barely mentioned and the term 'animal' does not even appear in the index. This is despite the fact that the three foundational categories Kelsey chooses to describe the human apply equally to other animals. 'Living on borrowed breath' is a recollection of human origins in God's breathing into Adam's nostrils (Gen. 2.7), but we need to note in this context that the biblical category neshama, creatures with the breath of life, encompasses all animals, human and other-than-human (e.g. Ps. 150.6). All animals are living on borrowed breath, therefore, not just the human ones. Similarly, all creatures belong to Kelsey's second category of living on borrowed time, as is made most clear in Paul's image of all creation waiting with eager longing (Rom. 8.19). Nor can Kelsey's final category of living by another's death be restricted to human beings alone, as we will see later with reference to the cosmic

${ }^{20}$ David H. Kelsey, Eccentric Existence: A Theological Anthropology (Louisville, Kentucky: Westminster John Knox, 2009). 
Christologies of Colossians and Ephesians. This detachment of humanity from the rest of creation seems to be more popular in modernity than previously: the standard Greek definition of the human as 'the rational animal', which Christian theologians were happy to receive, may have overstated human uniqueness, but at least recognised that humanity was a kind of animal creature, in accordance with biological classifications dating at least from Aristotle. Here, then, is a second mode of not-animal theological anthropology: doing anthropology as if humans had no fellow-animal neighbours.

It is clear, I hope, even from this brief survey, that the not-animal mode of doing anthropology, either through a reflection on supposed differences between humans and other animals, or through ignoring them entirely, is widespread and influential in theological accounts. The extent to which the arguments I have cited seem routine, indicates the ease with which we could multiply theological examples of the deployment of these arguments. In addition, we should note that not-animal anthropology in the mode of identifying rationality as the key differentiating factor between humans and other earthly creatures, and the claim that rationality is a common attribute of human beings, heavenly beings, and God, has origins well before and beyond theological anthropology, and is especially closely connected to Stoicism. The obvious question that follows is whether there are good theological reasons for avoiding structuring theological anthropology in this way.

\section{The problems with not-animal theological anthropology}

In my judgement, there are three key reasons Christian theologians ought be uncomfortable with not-animal theological anthropologies, which I outline below.

\section{a. Not-animal anthropology is not-theological anthropology}

Not-animal anthropology in the mode of constructing human identity on the basis of differences from other animals, it seems to me, is exactly how one would - and perhaps should - go about an anthropological project if one did not believe in Christianity. For those who subscribe to core Christian doctrines such as the incarnation, the Bible as the revealed word of God, and theism rather than deism, it is surely clear that the foundation of theological anthropology must be the confession of God as creator, reconciler and redeemer and the implications of this past, present and future for the living of human lives. It would be 
an almost inexplicable error to turn one's gaze from Christ as the true image of God (Col. 1.15), to close the covers of the book of God's revealed word, to block up one's ears to the promptings of the indwelling Spirit, and instead to seek to find a definition of the human through differential comparison with those creatures we find alongside us. This would be a form of practical atheism, going about the anthropological task as if Christianity were not true.

As I indicated in the opening to this paper, perhaps alert to this danger of being adrift from theological moorings, Christian theologians have found biblical authority for not-animal anthropology in the Genesis 1 claim that humanity is made in the image of God (1.26-27). If read with a prior commitment to the Stoic claim that rationality is a common attribute between the gods and human beings and is unique to human beings among earthly creatures, then it is natural to assume that the image of God must be rationality itself. Without such allegiance to Stoicism, it is highly implausible to interpret the image of God as rationality here, or to consider it equivalent to any other uniquely human faculty. Dismissing such attempts in commentary on this verse, Gordon Wenham comments that, given the sparsity of references to the image of God in the Old Testament, it is impossible to demonstrate any such claim, and one suspects that commentators are reading their own favourite human attributes into the text. ${ }^{21}$ The Genesis text here cannot, therefore, be used as licence for not-animal anthropology: we need to seek the meaning of human living in the Bible, not insert independent anthropologies into gaps in the text. Clearly, Genesis here and in the verses that follow envisages a distinctive identity for human beings among God's creatures, but it is given in God's command, not left for humans to discover by deduction on the basis of zoological observation. ${ }^{22}$

${ }^{21}$ Gordon J. Wenham, Genesis, Word Bible Commentary (Waco: Word, 1994), p. 30.

${ }^{22}$ For further discussion of the image of God in this context, see David Clough, $\underline{O n}$ Animals: I. Systematic Theology (London: T \& T Clark/Continuum, 2012), pp. 64-7 and pp. 100-2; J. Richard Middleton, The Liberating Image: The Imago Dei in Genesis 1 (Grand Rapids, MI: Brazos, 2005); J. Wentzel van Huyssteen, Alone in the World: Human Uniqueness in Science and Theology (Grand Rapids, MI: Eerdmans, 2006), pp. 111-62; Richard Briggs, 'Humans in the Image of God and Other Things Genesis Does Not Make 
One might initially think that the doctrine of the incarnation itself could be used to authorise not-animal anthropology in place of the Genesis text, on the grounds that God's choice to take on human creatureliness must have been as a result of the unique attributes of humanity, or established a new status for humans among God's others creatures. Following this logic, the incarnation could be seen as the ultimate establishment of a theological division between humanity and other creatures. This would be, however, to misread the particularity of the incarnation. First, it is a Christological mistake to consider the incarnation as an event with relevance only for the species Homo sapiens. The openings of the Gospel of John and the letters to the Ephesians and Colossians state clearly that through Christ all things were created (John 1.3; Co1. 1.16); through Christ God was pleased to reconcile all things to God by making peace on the cross (Col. 1.20); in the fulness of time all things on heaven and earth will be gathered up in him (Eph. 1.10). This means that the incarnation must be reckoned as nothing less than a cosmic event. Second, within this cosmic context, the incarnation does not establish a divine boundary between the human and non-human. Given the scandal of the belief that God became a particular earthly creature at a particular place and time within salvation history, theologians are confronted with the question of which, if any, of the attributes of the creature in which God became incarnate should be considered as bearing theological significance. Christians are clear that the incarnation does not mean only creatures that are the contemporaries of Jesus Christ can be saved, or that the incarnation sets up a boundary between those who are geographically proximate to where Jesus spent his life and those who live in other parts of the world. This means that neither the chronological nor the geographical particularity of the incarnation have final theological significance. Some theologians and ecclesial traditions believe that the gender of the creature in which God was incarnate has relevance, but I think we have good reason to deny this and claim instead that the incarnation does not represent the divine privileging of male over female. Given these

Clear', Journal of Theological Interpretation 4:1 (2010). David Kelsey comments that all attempts to characterize the human based on particular characteristics share in the major drawback that they rely 'on a property that undoubtedly characterizes most living human bodies, but only in varying degrees' (Kelsey, Eccentric Existence: A Theological Anthropology, p. 258). 
rejections of the theological significance of other particularities of the incarnation, it is far from clear why the species of the creature in which God became incarnate should be of decisive significance. God had to become incarnate as one kind of creature rather than another; we do not have reason to interpret this necessity as God's disfavour of every other kind of creature. ${ }^{23}$

Neither Scripture nor this aspect of doctrine, therefore, provide authorization for defining human identity in a theological context by ignoring Jesus Christ, the Bible and the inspiration of the Spirit in favour of the not-animal project of comparing creaturely differences, or ignoring the context of humanity amongst God's other creatures.

\section{b. Not-animal anthropologies are falsified by knowledge of other animal lives}

In the discussion of Descartes's defence of the eternal nature of the soul, above, I noted that any suggestion that the borderlines between humanity and non-humanity and rationality and irrationality were not perfectly coincident would be fatal to his argument. Unfortunately for Descartes, and for other theological arguments structured similarly, it is even clearer now than it was in the seventeenth century that the exclusive identification of rationality with humanity cannot be defended. There are various ways of demonstrating this. Most striking, perhaps, are the new examples of the capacities of other animals reported on an almost daily basis. We have learned that sheep can recognise hundreds of faces; ${ }^{24}$ crows can make tools to solve problems ${ }^{25}$ chimpanzees demonstrate empathy, morality and politics ${ }^{26}$ and better

${ }^{23}$ For further discussion of this point, see Clough, On Animals I, 83-4; Stephen H. Webb, On God and Dogs: A Christian Theology of Compassion for Animals (New York; Oxford: Oxford University Press, 1998), p. 170.

${ }^{24}$ Keith M. Kendrick, 'Sheep Don’t Forget a Face', Nature 414:4860 (2001).

${ }^{25}$ Alex A. S. Weir, Jackie Chappell and Alex Kacelnik, 'Shaping of Hooks in New Caledonian Crows', Science 297:5583 (2002). The video showing a female crow surprising researchers by bending a straight piece of wire into a hook to reach food is available here: $<$ http://www.sciencemag.org/content/297/5583/981/supp1/DC1>.

${ }^{26}$ Frans de Waal, Good Natured: The Origins of Right and Wrong in Humans and Other Animals (Cambridge, MA: Harvard University Press, 1996); Frans de Waal, Chimpanzee 
human subjects in numerically-based memory tests $;{ }^{27}$ dolphins can parse grammar; ${ }^{28}$ and parrots can differentiate between objects in relation to abstract concepts such as colour and shape. $^{29}$

Unless one rejects out of hand the veracity of such studies demonstrating that other animals are capable of tasks associated with what we used to consider uniquely human rationality, one requires a defensive strategy to maintain the claim that humans are the only rational earthly creatures. One could raise the stakes in one's definition of rationality, for example, by arguing that no other creatures, so far as we know, are capable of abstract differential calculus or writing a novel. The difficulty with such a move is that while it succeeds in identifying an ability that only humans are known to possess, only a tiny minority of humans, past or present, have possessed such a capability. Therefore, if we use these criteria to differentiate, a small group of humans belong on one side of our dividing line, and all other humans are lumped with all non-human earthly creatures on the other. ${ }^{30}$ To avoid

Politics: Power and Sex Among Apes (Baltimore: Johns Hopkins University Press, 1998).

${ }^{27}$ Sana Inoue and Tetsuro Matsuzawa, 'Working Memory of Numerals in Chimpanzees', Current Biology 17:23 (2007). The remarkable videos of the experiment are available on the website of the Primate Research Institute of Kyoto University (URL: $<$ http://www.pri.kyotou.ac.jp/ai/video/video_library/project/project.html >).

${ }^{28}$ Louis M. Herman, Stan A. Kuczaj and Mark D. Holder, 'Responses to Anomalous Gestural Sequences By a Language-Trained Dolphin: Evidence for Processing of Semantic Relations and Syntactic Information', Journal of Experimental Psychology: General 122:2 (1993).

${ }^{29}$ Irene M. Pepperberg, The Alex Studies: Cognitive and Communicative Abilities of Grey Parrots (Cambridge, MA: Harvard University, 2000).

${ }^{30}$ Elsewhere, I have noted that attempts to use human characteristic X to define a human/ non-human boundary that will be relevant in moral decision-making need to overcome three challenges: justification (Why should X be morally relevant?); boundary-matching (Does X reliably differentiate between all humans and all non-humans?); and degree (Is possession of $\mathrm{X}$ a matter of degree and, if so, are we committing to higher moral valuation for humans with more X?). Rationality, novel writing and abstract calculus each seem to fail all three tests. 
this, we could claim that all humans have the potential to succeed at these achievements, but we need only to state such a claim to recognise its falsity. In fact, the only way of maintaining the unique identification between rationality and humanity that seems promising is to resort to doing so by definition: the philosopher Jonathan Bennett states that he uses " to mean "whatever it is that humans possess which marks them off, in respect of intellectual capacity, sharply and importantly from all other known species"”. ${ }^{31}$

As well as making false representations in relation to the capacities of other animals, not-animal anthropologies have two related unhappy consequences. The first, in relation to human beings, is captured in Giorgio Agamben's account of the operation of the 'anthropological machine'. In his work The Open, Agamben argues that Homo sapiens does not name a species or substance, but 'a machine or device for producing the recognition of the human'. ${ }^{32}$ In its operation, the machine creates a 'zone of exception' between the human and the animal, which contains 'life that is separated and excluded from itself-only a bare life'. ${ }^{33}$ Pygmies, orang-utans, satyrs, sphinxes, ape-men, and Jews, are just some of the beings who have been exiled to this zone by the workings of the anthropological machine, Agamben argues, and he portrays the Nazi concentration camps as a realization of the machine, 'a monstrous attempt to decide between the human and the inhuman' $\cdot{ }^{34}$ While we persist in

(David Clough, 'The Problem With Human Equality: Towards a Non-Exclusive Account of the Moral Value of Creatures in the Company of Martha Nussbaum', in Transforming Exclusion: Engaging Faith Perspectives, eds. Hannah Bacon, Wayne Morris and Steve Knowles (London; New York: T \& T Clark International, 2011), p. 83.)

${ }^{31}$ Jonathan Bennett, Rationality: An Essay Towards an Analysis (Indianapolis: Hackett, 1989), p. 5, cited in Donna Yarri, The Ethics of Animal Experimentation: A Critical Analysis and Constructive Christian Proposal (Oxford: Oxford University Press, 2005), p. 33.

${ }^{32}$ Giorgio Agamben, The Open: Man and Animal, trans. K. Attell (Stanford, CA: Stanford University Press, 2004), p. 26.

${ }^{33}$ Agamben, The Open: Man and Animal, p. 38.

${ }^{34}$ Agamben, The Open: Man and Animal, pp. 25, 37, 22. 
constructing what Brian Brock terms 'best-case anthropologies', ${ }^{35}$ where normative human characteristics are established and then creatures measured up against them to determine whether they are to be included in the category of the human, there is no escaping the operation of the anthropological machine, or the dire consequences for those caught up in its machinations.

The second problematic consequence of false claims of human/non-human difference falls not on human beings, but on non-human animals. Where 'human' and 'animal' are used as exclusive categories in the context of anthropology, 'animal' becomes a negative category, erasing the particularity of non-human creatures in order to make use of them merely to frame the human. Jacques Derrida calls this a bêtise,_or asinanity:

Confined within this catch-all concept, within this vast encampment of the animal, in this general singular, within the strict enclosure of this definite article ("the Animal" and not "animals"), as in a virgin forest, a zoo, a hunting or fishing ground, a paddock or an abattoir, a space of domestication, are all the living things that man does not recognise as his fellows, his neighbors, or his brothers. And that is so in spite of the infinite space that separates the lizard from the dog, the protozoon from the dolphin, the shark from the lamb, the parrot from the chimpanzee, the camel from the eagle, the squirrel from the tiger or the elephant from the cat, the ant from the silkworm or the hedgehog from the echidna. ${ }^{36}$

Once we use animals as means to the end of establishing human identity in this way, we can no longer recognise them for what they are, in their particular modes of creaturely being. Adam's first God-given human task was to encounter and recognise the animals in Eden and give them their proper names (Gen. 2.19-20); not-animal anthropologies put this process into reverse - having lost our bearings as human creatures we use other animals as props for our

${ }^{35}$ Brian Brock, 'Introduction: Disability and the Quest for the Human', in Disability in the Christian Tradition: A Reader, eds. Brian Brock and John Swinton (Grand Rapids, Mich.: Eerdmans, 2012), p. 1.

${ }^{36}$ Jacques Derrida and David Wills, 'The Animal That Therefore I Am (More to Follow)', Critical Inquiry 28:2 (2002), pp. 400, 402. 
own identity, distorting their shapes and taking away their named particularity. In her discussion of the way women feature in the pre-history of accounts of the Great Chain of Being, Page duBois observes that the Greek man is identified as first not-animal, then notbarbarian, then not-female: the structural similarities between not-animal modes of constructing human identity, racist constructions of white identity in opposition to non-white, and sexist constructions of male identity in opposition to female, are hard to miss. ${ }^{37}$

\section{c. Not-animal anthropologies misrepresent the particularity of humanity}

Imagine that I were to give a self-description without reference to the fact that I am human, and there are lots more humans like me. My account would be obviously partial and inaccurate: I would give the impression that characteristics such as my ability to stand on my hind legs and talk were more significant than in fact they are; I would give the impression that I could be understood independent of my human relationships; and in many other ways I would tend towards the deficiencies of solipsism. In an analogous way, if we give an account of the human without recognizing our place alongside other creatures in the vast expanse of God's creative and redemptive project, we are guilty of species-solipsism, generating inaccuracies that overstate human particularity and significance, ignoring our intricate and multiple relationships and dependencies on other creatures, and suggesting, contrary to the biblical themes we have already surveyed, that it makes sense to think of the human in isolation. Theological anthropology done in a vacuum, then, where human beings are seen without the context of other creatures, is as dangerous a mistake as defining human identity through difference from animals: it is a second kind of not-animal theological anthropology, which fails to see the relevance at all of the animality of human beings for their identity. Again, this is not just a bad account of the human and our fellow creatures, it is a theological error with potentially serious consequences. Colin Gunton associates Basil of Caesarea with the recognition of the 'ontological homogeneity' of all creation, in which, 'against the

\footnotetext{
${ }^{37}$ Page duBois, Centaurs and Amazons: Women and the Pre-History of the Great Chain of. Being. (Ann Arbor, MI: University of Michigan Press, 1982), p. 4.
} 
assumptions of almost the whole of the ancient world', there are no degrees of being ${ }^{38}$ In the species-solipsism of this second not-animal anthropology, we are in danger of undoing Basil's work, positing ourselves as an exception to the rule that creatures have the same ontological status before God, and reckoning ourselves as an exception to the rule.

\section{The vocation of the human animal creature}

If my diagnosis and evaluation of not-animal theological anthropologies is correct, we would do well to look for alternatives to it. I do not, unfortunately, have space for a developed proposal, but suggest the following two complementary guidelines for theological anthropology to avoid the difficulties I have outlined thus far.

First, theological anthropology should avoid the first kind of not-animal anthropology by taking as its starting point our understanding of the relationship between God and humanity, rather than our understanding of the difference between human beings and other creatures. To do so avoids both the not-animal approaches we have seen to be theologically problematic and the problematic consequences for construals of human identity and the identities of other animals. Kelsey's account makes clear that nothing is lost and much is gained by a theological anthropology that turns its face away from an account based on differentiation from other animals and defines human identity outside the competitive logic that establishes human attributes through denying them to other animals.

Second, theological anthropology should avoid the second kind of not-animal anthropology by recalling that this divine-human relationship takes place in the context both of God's relationship with God's other creatures and human existence alongside these other creatures. God has other creatures, as God's speech to Job reminded him (Job 38-41) and we have non-human fellow creatures. Both these facts are relevant to the project of theological anthropology; both will help us guard against replacing theocentrism with anthropocentrism and humility with hubris. ${ }^{39}$ To avoid the species-solipsism I diagnosed at the end of the

\footnotetext{
${ }^{38}$ Colin E. Gunton, The Triune Creator: A Historical and Systematic Study (Edinburgh: Edinburgh University Press, 1998), pp. 71-72.

${ }^{39}$ Some theologians have argued recently that it is anthropomonism that is the problem here, rather than anthropocentrism (see, for example, Lukas Vischer, 'Listening to Creation
} 
previous section is not to give up on human uniqueness: clearly human beings have a unique place in God's creative, reconciling and redemptive purposes - just like every other kind of creature of God. Just as one's uniqueness as a person does not depend on denial of the characteristics one shares with other human beings, so the particularity of the human creature is not at stake in recognizing our close relationships with other members of the creation community. We can therefore give an account that represents our foundational identity as one of God's creatures, recognizing the many other creatures we live alongside

While I cannot here develop a substantive positive proposal for a theological anthropology pursued along these lines, my subtitle, 'the vocation of the human animal creature', is an indication of what looks to me to be a promising starting point. Construing anthropology as human vocation frames clearly my argument that our identity must be

Groaning: A Survey of Main Themes of Creation Theology', in Listening to Creation Groaning: Report and Papers From a Consultation on Creation Theology Organised By the European Christian Environmental Network At the John Knox International Reformed Center From March 28 to April 1st 2004, ed. Lukas Vischer (Geneva: Centre International Réformé John Knox, 2004), pp. 21-22, discussed in Christopher Southgate, The Groaning of Creation: God, Evolution, and the Problem of Evil (Louisville; London: Westminster John Knox, 2008), p. 93; Francis Watson, 'In the Beginning: Irenaeus, Creation, and the Environment', in Ecological Hermeneutics: Biblical, Historical and Theological Perspectives, eds. David Horrell, Cheryl Hunt, Christopher Southgate and Francesca Stavrakopoulou (London; New York: T \& T Clark International, 2008), p. 4), where anthropomonism is taken to mean concern only for the human, whereas anthropocentrism denotes a central concern for the human with the acknowledgement that other creatures may be of peripheral concern. The difficulty here is the wide range of potential meaning of 'anthropocentrism'. Francis Watson says that anthropocentrism is inevitable for us, because our perspective is human ( $\underline{\text { loc. cit. }}$ ), but it is by no means clear that this perspectival anthropocentrism has any relevance for a judgement concerning whether God created everything for the sake of human beings, for example. A useful comparison here is egoism: because we see the world from our own point of view does not commit us to the moral view that we are more important than other human beings. I discuss kinds of anthropocentrism in Clough, On Animals I, pp. xvi-xx. 
discovered in relationship with and in response to God; naming ourselves as one of God's

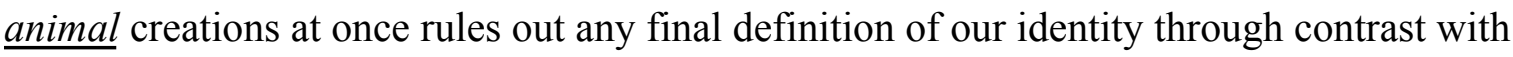
other animals and ensures that our anthropology is grounded in the animality we share with our closest creaturely neighbours; creature recalls the solidarity in creatureliness in which we exist alongside everything that God has made. We find what it means to be human in encounter with God in the context of our network of relationships with other human beings, other animals, and other creatures.

Clearly, any theological anthropology has consequence for how we think about the proper role and responsibilities of human beings and connects at every point to the project of theological ethics. Such a connection with ethics is particularly obvious in relation to the correction to theological anthropology I have proposed here. It seems to me that once we have given up on anthropologies that construct our identity at the cost of God's other animal creatures, we will have cause to reconsider more practical ways in which modes of human living are only possible at severe cost to other animals. If we give up on consuming animals theoretically in the service of not-animal theological anthropologies, we might also have reason to give up on consuming animals practically, especially where farming conditions treat them as not-animals, such as the factory farming of chickens and pigs. ${ }^{40}$

\footnotetext{
${ }^{40}$ The second volume of my On Animals monograph, 'Theological Ethics' will address the implications of Christian understandings of animals for the human practice of killing animals for food, together with other areas of human/non-human animal relationships.
} 